\title{
The Role of Osteosynthesys Materials in the Etiopathology of Bone Malignant Tumors and Reconstruction Possibilities
}

\author{
Case report
}

\author{
CEZAR IONUT CALIN ${ }^{1}$, MARINEL DRIGNEI ${ }^{2}$, STERGIOS GANATSIOS ${ }^{3}$, ERIC JOVENET ${ }^{4}$, GEORGE DINACHE ${ }^{1,5 *}$, \\ FLORIN SAVULESCU1, DUMITRU FERECHIDE ${ }^{5}$ \\ ${ }^{1}$ Dr. Carol Davila Central Universitary Emergency Military Hospital, 134 Calea Plevnei Str., 010825, Bucharest, Romania \\ ${ }^{2}$ Abbeville Hospital Center, Abbeville, France \\ 'T.E.I.W.M., Kila Kozanis, 50100, Kila, Greece \\ 4J MS, 1929 Seche Rue, 62149, Festubert \\ ${ }^{5}$ Carol Davila University of Medicine and Pharmacy Bucharest, 37 Dionisie Lupu Str.,020021, Bucharest, Romania
}

\begin{abstract}
The use of osteosynthesis materials in orthopedics is fundamental in the surgical management of patients presenting with various pathologies of the locomotor system, in most cases trauma, but also malign and benign tumors. The risk that these materials could have in inducing malignant transformation of benign tumors or in the onset of primary malignant tumors, was rarely studied. On the one hand, primarymalignant tumors of the locomotor system are much less frequent than other kind of neoplasms (for example Ewing sarcoma has an incidence of 1-3 cases / 1.000.000 people / year, ostosarcoma has an incidence of 2 cases / 1.000.000 people / year). On the other hand, usually there is a time window of several years, different from one case to another, from the moment of action of the etiopathogenic factor to the moment of revealing the presence of a neoplastic disease. Based on our clinical practice on a few clinical cases, we intend to study more thoroughly the etiology of primary bone malignant tumors in general and the role of the osteosynthesys materials in this matter especially.
\end{abstract}

Keywords: osteosynthesis materials, bone malignant tumors

There are many favoring factors or triggers we can include in the etiopathogeny of malignant tumors [1]. There are two types of carcinogens: exogenous and endogenous carcinogens. Exogenous carcinogens include chemical substances, drugs, ionizing radiation, infectious agents. Endogenous carcinogens include defective DNA repair mechanisms, defective regulation of epigenetic events, genetic instability. In the pathogeny of osteosarcoma, the literature describe some risk factors: genetic predisposition in primary osteosarcoma (patients with hereditary retinoblastoma, Li-Fraumeni syndrome) and radiotherapy, therapy with alkylating agents, fibrous dysplasia, bone cysts, or osteitis deformans (Paget's disease) in secondary osteosarcomas [2]. Cell biology research of osteosarcomatous cells describes many types of molecular and genetical abnormalities:

- expression of the c-sis protooncogene and subsequent secretion of platelet-derived growth

factor (PDGF, stimulates proliferation of mesenchymal cells);

A CLASSIFICATION OF OSTEOSYNTHESIS MATERIALS IN ADULTS

- inactivation of tumor suppressor genes such as pRB110 $(\mathrm{Rb})$ and $\mathrm{p53}$;

- oncogene expression (ras, raf, mos, myc, fos) or oncornavirus.

The possible role that osteosynthesys materials could play in the process of inducing malignant tumors, would place them on the list of exogenous carcinogens.

There are many kinds of osteosynthesis materials used in the surgical practice and they could be divided as in the following classification (table 1).

Besides the ostheosynthesis matherials currently used in orthopaedic practice [3-6], there are also metallic bone augment medical devices [7], designed to be used as a means of reconstructing a bone defect, such as in hip and knee surgery. These augments vary in size and shape, and in some cases may be custom made for a particularly challenging defect [8]. In order to evaluate the bone defect and decide on the type of augment to be used, a CT or MRI scan may be used as a source of visual information in order

Table 1

\begin{tabular}{|c|c|c|c|}
\hline Class & Sub-Class & Type & Example \\
\hline \multirow[t]{9}{*}{ Non-resorbable } & \multirow[t]{2}{*}{ Intra-medullary } & Rigid (interlocking) & $\begin{array}{l}\text { The Russel-Taylor Nail } \\
\text { The Gamma Nail }\end{array}$ \\
\hline & & Non-rigid & The Ender Nail \\
\hline & \multirow[t]{5}{*}{ Extra-medullary } & Non-locking plates & $\begin{array}{l}\text { The reconstruction plate } \\
\text { The compression plate }\end{array}$ \\
\hline & & Locking plates & The PHII OS \\
\hline & & Plate and Screw Systems & $\begin{array}{l}\text { The DCS } \\
\text { The DHS }\end{array}$ \\
\hline & & Screws & $\begin{array}{l}\text { Cortical screws; Cancellous screws; } \\
\text { Malleolar screws }\end{array}$ \\
\hline & & Pins / wires & The Kirschner wire \\
\hline & \multirow[t]{2}{*}{ External fixation } & Rigid & $\begin{array}{l}\text { The AO fixator } \\
\text { The Ilizarov fixator }\end{array}$ \\
\hline & & Distractor & The ProCallus fixator \\
\hline \multirow{3}{*}{\multicolumn{2}{|c|}{ Resorbable }} & Plates & The PLLA plates \\
\hline & & Screws & The Bio-Compression Screw \\
\hline & & Pins & The Trim-It pin \\
\hline
\end{tabular}

*email: dinach3_g3org3@yahoo.com

All authors have participated equally in developing this article. 
to create a 3D image of the defect [9-11], which may be $3 D$ printed [12-14], giving the surgical team a better understanding of the area to be reconstructed [15].

Often times, the biomaterials used in orthopaedic surgery are neither ostheosynthesis matherials nor bone augments, but endoprothetics. These are used generally to replace worn-down joints, such as an uncemented or cemented knee prosthesis [16] for a patient whose ostheoarthrosis has progressed beyond conservative or arthroscopic treatment, [17-20] but a certain type of prosthesis, the reconstructive prosthesis, which are used to rebuild a joint and/or portion of bone that was removed during radical tumor surgery. Reconstructive surgery of the joints, especially of the hip or knee, if not planned out and executed with precision, may lead to modifications in the axis of movement of the limb, potentially leading, in time, to degenerative wear of the unaffected joints or alterations in the balance of the spine and pelvis or the plantar arches and plantar fasciitis [21]. In other cases, biomaterials in orthopadic surgery are simply the materials with which an amputation stump comes into contact, such as in myoelectric commanded exoprosthetics [22-25] Also of noted importance is the preoperative preparation of the patient, with pre-existing conditions being evaluated, both in themselves as well as the efficiency of their treatment $[26,27]$.

Because of the low incidence of primary bone tumors and because of the diversity of surgical procedures and ostheosynthesys materials used in orthopedic practice, it is very difficult to develop comparative randomised studies or trials which expand during many years of following up the patients who develop bone malignancies [28-29]. The issue we raise has been rarely addressed in the literature.

\section{Experimental part}

\section{Materials and methods}

We present a case-report with a long clinical evolution that we consider relevant from the scientific point of view. It is a case-report that aroused our interest for such a research. It is not our intention to bring allegations of any kind on the industry that proved so helpful in developping so many and so performant materials, but we consider scientific research of any possible correlation between longterm presence of osteosynthesys materials and the onset of oncogenic process, is beneficial to everybody and especially to the future patients.

The case is that of a 27 years old female patient with a long orthopedic and oncologic history. At the age of 13 years old she was admitted in the Orthopedic Department of "Marie Curie" Clinical Universitary Children Hospital for a fracture on the femural right neck which had apeared on pathological bone (essential bone cyst). The treating physician immobilised the hip with gipsum casts for aproximately a month. There was, at the time, a noted shortening of the right lower limb of $3 \mathrm{~cm}$. Six months later, at the age of 14 , the right limb was $4 \mathrm{~cm}$ shorter that the left limb. The evolution was considered favorable until the age of 19 years old, when she developed an important asymmetry between the lenghts of pelvic limbs and she presented in our hospital with pain and functional deficiency in the right hip. She was evaluated clinically and submitted to radiological investigations. The diagnostic was cystic tumor in the proximal metaphysis of the right femur and vicious trohanto-cervical callus with secondary coxa vara, associated with a limb length discrepancy of $4 \mathrm{~cm}$.

The orthopedic surgeons performed a percutaneous bone biopsy on the 29th of September 2010 and recomended orthopedic conservatory treatment. The pathological report revealed no cancer cells in the specimen and described inflamatory process instead (fig. $1)$.

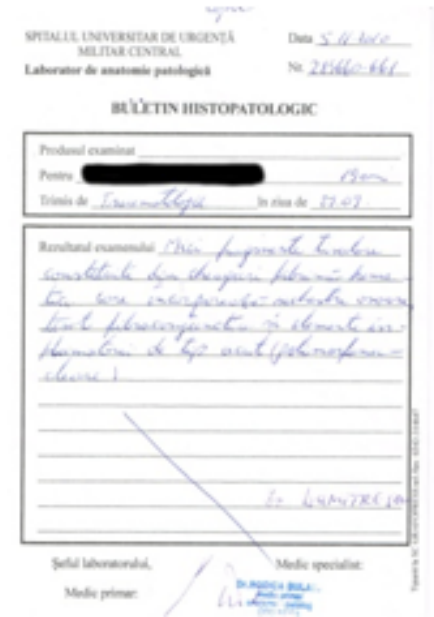

Fig. 1. H-P report 2010

The patient returned to the hospital and in december 2010 she was operated. The orthopedic surgical team performed a curetage of the cystic lesion, Pauwels valgisation osteotomy and osteosynthesys with Dynamic Condylar Screw adding structured autograft from the patient's iliac crest in the osteotomy hotbed and filling in the remaining cavity of the cyst with an osteoinductive substance silicate-substituted calcium phosphate graft a bone filler used in orthopedic applications as a filler for defects in the structure of a bone in areas that do not directly transmit forces; it is inteded for use in cancellous bone defects and not cortical bone defects, and has similar fusion rates as illiac crest graft [30]. The evolution was favorable after the surgical intervention and the patient was periodically followed up clinically and radiologically.

Six years later, in 2017, the patient presented again with pain and functional deficiency in the right hip and the radiological investigations revealed a tumoral lesion grown at the same site as the previous cystic lesion. She was admitted in our Orthopedic Clinic. Firstly, a biopsy was performed and the result of the pathological report was parosteal osteosarcoma. The right lower limb was arteriographed via a femoral arterial approach and the results showed a well vascularised tumoral mass, located proximally in the thigh, arterially fed through branches of the right deep femoral artery, mainly the circumflex femoral arteries (figs. 2-4).
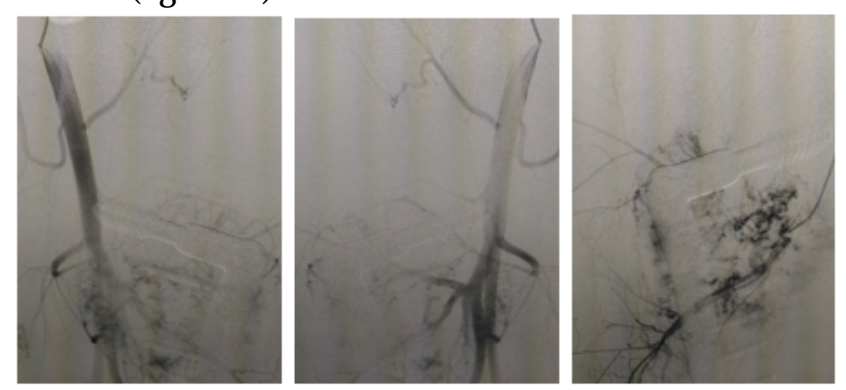

Figs. 2-4. Arteriography of the patient's right thigh showing, in different irrigation times, the vascularisation of the tumour

The cardiovascular team was involved and performed a right femoral arterial embolisation, after which a mixed Orthopedic and General Surgery team of surgeons performed a segmentary resection of the tumoral mass and of the proximal femur, together with the infiltrated parts of the local musculature (fig. 5), and in the same procedure 


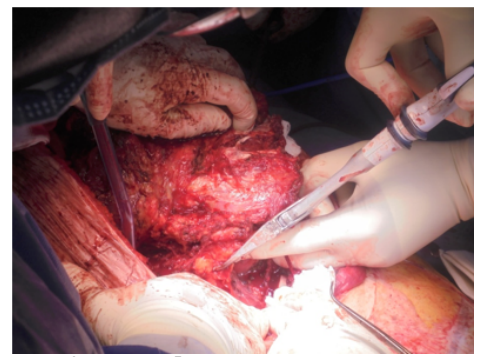

Fig. 5. Intraoperative image -tumor removal.

performed a reconstruction with bipolar modular cemented prosthesis of the right hip (fig. 6).

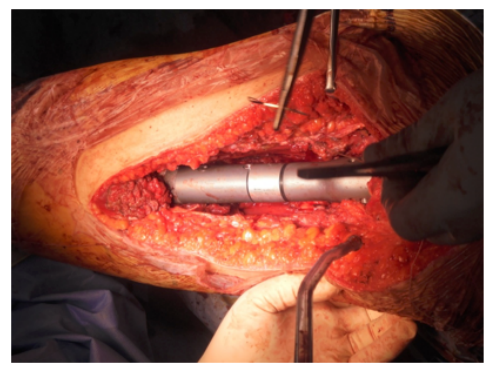

Fig. 6. Intraoperative image bipolar tumoral prosthesis reconstruction.

Postoperatively, the patient resumed walking with a protective brace and crutches as soon as the pain levels allowed it, eventually transitioning to full weight bearing and non-protected walking (fig. 7).

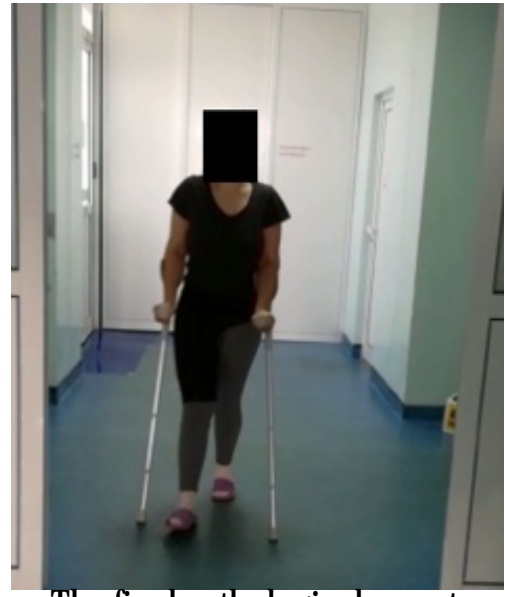

Fig. 7. Postoperative rehabilitation -the patient resumes walking with a protective brace and crutches.

The final pathological report on the resection specimen including the imunohystochemistry examination concluded the diagnostic of conventional osteosarcoma well differentiated (S100 low positive in tumoral cells and osteoclasts, CD56 highly positive difuse in tumoral cells, MDM2 positive in the nuclei in frequent tumoral cells, Ki-67 positive in aprox. $40 \%$ of tumoral cells) (fig. 8).

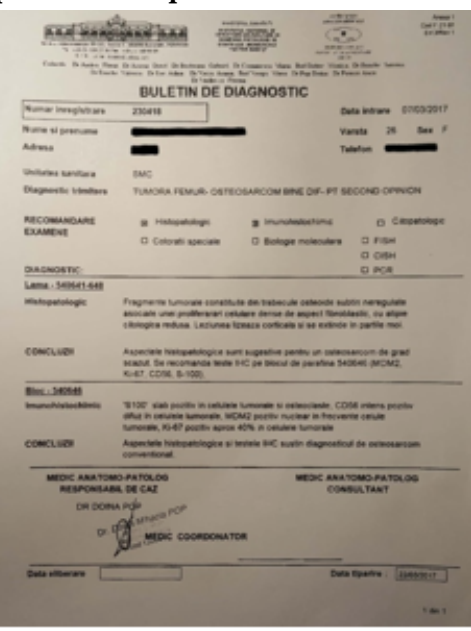

Fig. 8. The pathological report from 2017, full tumoral specimen.

The patient was addressed to the Oncology Department of our hospital with the pathology and radiological results. The patient had been investigated previously with computed tomography and MRI and there was no sign of distant dissemination of the neoplastic disease. Therefore the disease was staged IB (pT2 N0 MO G1 R0) [31], locally advanced, completely resected and the patient started adjuvant chemotherapy with Doxorubicin and Ciplatin endovenous injected protocol for 6 cycles every 21 days. The patient tolerated the chemotherapy difficultly due to the side effects of the cytostatics: important emesis, alopecia, hematological toxicities (low blood count in what concerns red cells and white cells). The side effects were reversible with supportive medication: antiemetics as Granisetron (5-hydroxytryptamine (serotonin) receptor 3 antagonist, mediates its effects centrally and peripherally through inhibition of serotonin effects ) and Dexamethasone (corticosteroid with different applications including antiemetic effect), granulocyte colony stimulating factors (GCS factors) such as Filgrastim to reverse leucopenia, epoetinum beta (analogue of erithropoetin, a natural hormone produced by the kidneys in order to stimulate the synthesis of the red cells in the bone marrow) to reverse the anemia induced by the chemotherapy.

Doxorubicin (DOX, DXR, Adriamycin) is an anthracycline, hydroxydaunorubicin, antineoplastic glycoside antibiotic that acts by DNA intercalation, induction of DNA strand breaks, generation of free oxygen radicals, inhibition of topoisomerase II and is cell-cyclespecific: S/G2 phases (32) (fig. 9).

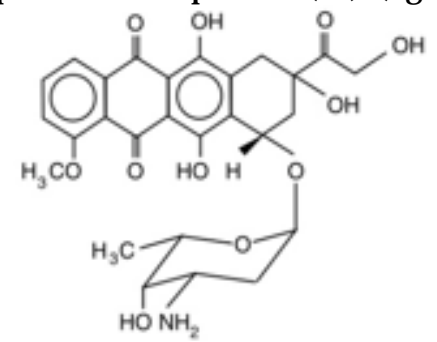

Fig. 9. The chemical formula for Doxorubicin

Cisplatin (CDDP): cis-Diamminedichloroplatinum(II) cis-[PtCl( $\mathrm{NH} 3) 2(\mathrm{H} 2 \mathrm{O})]$, platinum derivative, is a cytostatic alkylating - like drug that acts by covalent binding of platinum complexes to DNA, RNA, and proteins, crosslinking and is cell-cycle-specific: G1/S phases [32] (fig. 10).<smiles>N[PH](N)(Cl)Cl</smiles>

Fig. 10. The chemical formula for Cisplatin

The tumor board commitee agreed that external beam radiotherapy was not necessary because the tumor was largely resected and a bipolar prosthesis was inserted in the right hip.

After the completion of the chemotherapy protocol, the patient was followed up with clinical, biological and radiological periodical investigations.

\section{Results and discussions}

Unfortunately the computed tomography performed in February 2018 revealed the presence of multiple metastasis in the lungs and one metastasis in the right hip (fig. 11-13). Therefore the stage and the prognosis of the disease changed significantly despite the adjuvant chemotherapy performed after the intervention.

A second line of chemotherapy was started, this time the treatment being with paleative intent in order to expand the overall survival. The chemotherapy protocol included Etoposide and Ifosfamide endovenous injected every 21 days. 

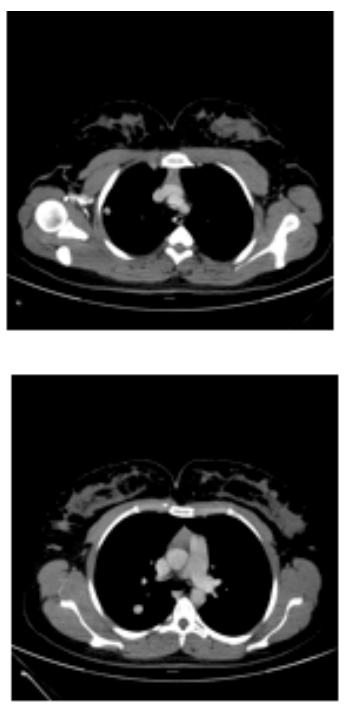

Figs. 11-13: CT scan showing multiple metastasis in the lungs

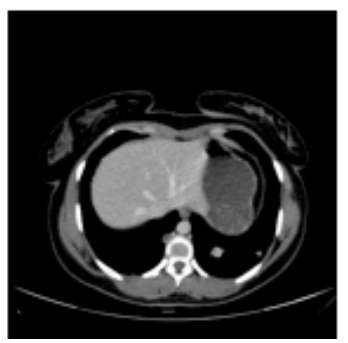

Etoposide (VP-16): 4'-Demethylepipodophyllotoxin 9$(4,6$-0-ethylidene-beta-D-glucopyranoside Epipodophyllotoxin derivative, plant alkaloid, topoisomerase II inhibitor; Etoposide phosphate is a water-soluble phosphate ester of the plant alkaloid; Etoposide acts by inhibition of topoisomerase II which induces mitotic arrest then DNA strand breaks; Etoposide is cell-cycle-specific: G2/S/M phases [32] (fig. 14).

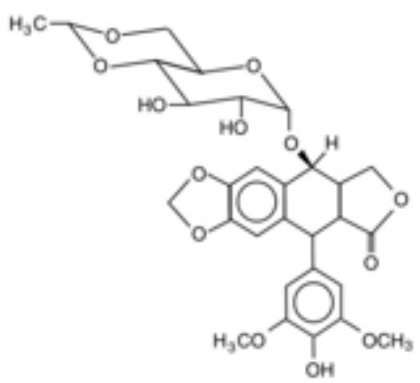

Fig. 14. The chemical formula for Etoposide.

Ifosfamide (IFO): N,3-Bis(2-chloroethyl) tetrahydro-2H1,3,2-oxazaphosphorin-2-amine 2-oxide

Oxazaphosphorine, bifunctional alkylating agent acts by DNA and RNA alkylation, DNA strand breaks, DNA intercalation, inhibition of DNA synthesis; Ifosfamide is cellcycle-specific: S phase [32] (fig. 15).

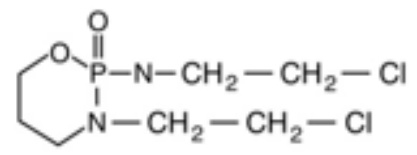

Fig. 15. The chemical formula for Ifosfamide

After 4 cycles of chemotherapy, a computed tomography was performed and the results were somehow encouraging showing partial response to the treatment, the metastasis in the lungs decreased dimensionally and no other metastasis in any other organ was seen (fig. 1618).
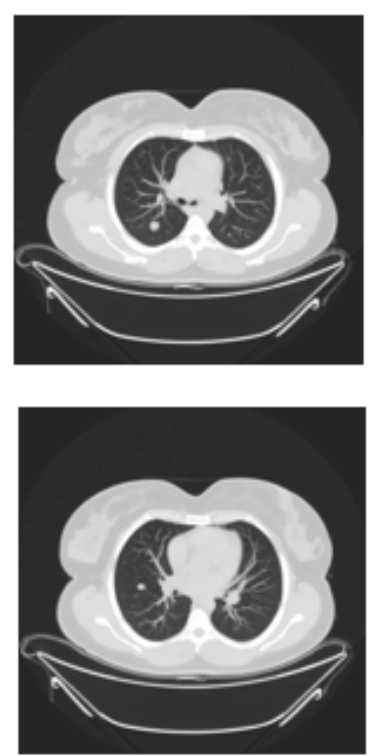

Fig. 16-18. CT scan showing a decrease in the size of the metastasis in the lungs

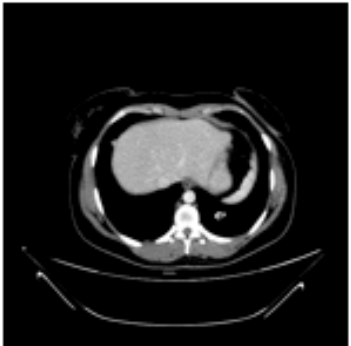

The patienthas been continuing the chemotherapy with Ifosfamide (monochemotherapy) since the last computed tomography and is under regular clinical and biological surveillance every visit in the Oncology Department.

The prognosis on longterm is not a very good one however, due to the fact that the disease is in the metastatic stage and could develop a new reccurence in time[33, 34]. Unfortunately ESMO and ASCO guidelines have no recommedation so far for immunotherapy which proved so beneficial in other kind of much more frequent cancers such as lung cancer or malignant melanoma. [35]. Strong evidence randomised clinical trials testing the new chemotherapy drugs or immunomodulators, need large numbers of enrolled patients with the same disease, a requirement so hard to comply with in the osteosarcoma group of patients.

The experimental work and clinical results obtained in this case study will be the basis for future research in which simulation of surgical intervention will be used in virtual medium environments with robotic systems [36 - 41].

\section{Conclusions}

The possible connection between the ostheosynthesis materials (at least some of them) and the development of bone cancer remains an issue to study and to validate or invalidate. One thing is for sure that a lot of research is needed in this direction, in vitro and in vivo laboratory comparative studies are necessary testing cell lines in the longterm presence of these materials. On the other hand, further prospective randomized trials regarding new chemotherapy or immunotherapy drugs are needed to establish the best protocol for the best therapeutic results, selecting the patients with bone malignant tumors and enrolling them in the trials, therefore a good cooperation between family doctors as primary care physicians, radiologists, orthopedic surgeons and oncologists, is mandatory. 


\section{References}

1. DEVITA V., LAWRENCE T., ROSENBERG S., DEPINHO R., WEINBERG R., DeVita, Hellman, and Rosenberg's Cancer: Principles and Practice of Oncology, Lippincot, Williams \& Wilkins, 9th edition, North American Edition, 2011.

2. WANG L.L., Biology of osteogenic sarcoma, Cancer J, 11, 2005, p. 294-305.

3.PAPIN P., BERTHONNAUD E., Incidence of osteosynthesis of members in France, Int Orthop., 41(8), 2017, p. 1501-6.

4.THOMSEN M., THOMAS P., [Compatibility and allergies of osteosynthesis materials], Unfallchirurg., 120(2), 2017, p. 116-21.

5.MUTSCHLER W., HÖNTZSCH D., [Steel or titanium for osteosynthesis?], Unfallchirurg., 120(2), 2017, p. 94-5.

6. OBOIRIEN M., AGBO S.P., AJIBOYE L.O., Evaluation of locked plate in the osteosynthesis of fractures in osteoporotic bones, Ann Afr Med., 16(3), 2017, p. 127-30.

7. RICKS M., FLYNN N., A novel way to augment a tibial prosthesis for significant bone loss, Ann R Coll Surg Engl., 97(5), 2015, p. 396.

8. MAKINEN T. ., ABOLGHASEMIAN M., WATTSE., FICHMAN S.G., KUZYK P., SAFIR O.A., GROSS AE., Management of massive acetabular bone defects in revision arthroplasty of the hip using a reconstruction cage and porous metal augment, Bone Joint J., 99-B(5), 2017, p. 607-13. 9. PLAVITU. A., POGARASTEANU. M.E., MOGA. M., BARBILIAN. C.R., STOICA. I.C., ROBU. G.C., OPROIU. A.M., JINGA. M., IFRIM. C.F., MRI versus $C T$ as image data source for 3D printing bone, Rev. Chim. (Bucharest), 69, no. 10, 2018, p. 2881-4.

10. KRCAH M., SZEKELY G., BLANC R., Fully automatic and fast segmentation of the femur bone from 3D-CT images with no shape prior, Proceedings of the 8th IEEE International Symposium on Biomedical Imaging: From Nano to Macro, Chicago, Illinois, USA, ISBI 2011, 2011.

11. ZHANGA J., YANA C.-H., CHUIB C.-K., ONG S.-H., Fast segmentation of bone in $\mathrm{CT}$ images using $3 \mathrm{D}$ adaptive thresholding, Computers in Biology and Medicine, 40(2), 2010, p. 231-6.

12. SEITZ H., RIEDER W., IRSEN S., LEUKERS B., TILLE C., Three dimensional printing of porous ceramic scaffolds for bone tissue engineering, J ournal of Biomedical Materials Research. Part B: Applied Biomaterials, 74B(2), 2005, p. 782-8.

13. INZANA J ., OLVERA D., FULLER S., KELLY J ., GRAEVE O., SCHWARZ E., KATES S., AWAD H., 3D printing of composite calcium phosphate and collagen scaffolds for bone regeneration, Biomaterials, 35(13), 2014, p. 4026-34.

14. PLAVITU, A., POGARASTEANU, M. E., MOGA, M., LUPUSORU, M., IONITA RADU, F., EDU A., 3D Printing as a Way of Integrating Mathematical Models in Arthroscopic Knee Surgery, Rev. Chim. (Bucharest), 69, no. 9, 2018, p. 2501-7.

15. WANG F., ZHU J., PENG X., SU J ., The application of 3D printed surgical guides in resection and reconstruction of malignant bone tumor, Oncol Lett., 14(4), 2017, p. 4581-4.

16. ADAM R., ORBAN C., ORBAN H., Comparative Study of Design and PCL-Substituting Systems of Total Knee Prosthesis, Chirurgia, 109(1), 2014, P. 99-103.

17. DENNIS M., DI CESARE P., Surgical Management of the Middle Age Arthritic Knee, Hospital for J oint Diseases, 61(3,4), 2003-2004, p. 172178.

18. MOGA, M., POGARASTEANU, M. E., EDU, A., Arthroscopy in Arthrosis: Is It Worth it? - A case Presentation, Rev. Chim. (Bucharest), 69, no. 8, 2018, p. 2232-5.

19. BRIGNARDELLO-PETERSEN R, GUYATT GH,BUCHBINDER R., Knee arthroscopy versus conservative management in patients with degenerative knee disease a systematic review, BMJ Open, 7, 2017, p. 1-12.

20. LYU S.R., HSU H.H., LIN C.W., Arthroscopic cartilage regeneration facilitating procedure for osteoarthritic knee, BMC Musculoskeletal Disorders,13(226), 2012, p. 1-10.
21. MOGA, M., POGARASTEANU, M. E., EDU, A., Arthroscopic Equipment Used in the Treatment of Calcaneal Spurs - A case presentation, Rev. Chim. (Bucharest), 69, no. 8, 2018, p. 2228-31.

22. S. OSICEANU, M. DASCALU, E. FRANTI, A. BARBILIAN, Intelligent Interfaces for Locomotory Prosthesis; IJ CNN: 2009 International J oint Conference on Neural Networks, Vol1-6; IEEE; IEEE International Conferences on Neural Networks (IJ CNN); Pages: 1933-1938; 2009; WOS: 000280591601024 . Atlanta, June 14-J une 19, 2009, USA

23. FRANTI E., MILEA L., BARBILIAN A., BUTU V., CISMAS S., LUNGU M., SCHIOPU P., Methods of acquisition and signal processing for myoelectric control of artificial arms, ROMANIAN JOURNAL OF INFORMATION SCIENCE AND TECHNOLOGY, volum 15, no. 2, 2012, p. 91-105.

24. MOLDOVAN, C., DOBRESCU, L., RISTOIU, V., FIRTAT,B., DINULESCU, S., BRASOVEANU, C., ION, M., DOBRESCU, D., GHEORGHE, R., PASCALAU, A.M., POGARASTEANU, M., COCULESCU, B.I., OPROIU, A.M., Experimental Measurements in the Acquisition of Biosignals from a Neuronal Cell Culture for an Exoprosthesis Command, Re. Chim. (Bucharest), 69, no. 10, 2018, p. 2948-2952.

25. OLTU, O., VOICULESCU, V., POPESCU, V., DASCALU, M., BARBILIAN, A., Advanced power monitoring of an ARM processor, Computational Engineering In Systems Applications, Book Series: Mathematics and Computers in Science and Engineering, 2008, p. 243-246.

26. COCULESCU, B.I., DINCA, G.V., MANOLE, G., PURCAREA, V.L., OPROIU, A.M., STOCHECl, C.M., Serum Concentration of hSCRP Possible Marker for Therapy Evaluation in Left Ventricular Dysfunction with Preserved Ejection Fraction, Rev. Chim. (Bucharest), 69, no. 10, 2018, p. 2885-990.

27. NITA, D., GURZUN, M., CHIRIAC, L., CIRSTEA, A.I., PAREPA, R.I., BARBILIAN, A.G., Impact of stent diameter and length on in-stent restenosis after bare metal stent implantation, Romanian Biotechnological Letters, 22, no. 2, 2017, p. 1234-12351

28. EYRE R., FELTBOWER R.G., MUBWANDARIKWA E., EDEN T.O.B., MCNALLY R.J.Q., Epidemiology of bone tumours in children and young adults, Pediatr Blood Cancer, 53(6), 2009, p. 941-52.

29. PAPAGELOPOULOS P., SAVVIDOU 0., GALANISE., ET AL. Advances and challenges in diagnosis and management of skeletal metastases, Orthopedics, 29(7), 2009, p. 609-20.

30.*** http://www. actifusebonegraft.com/us/actifuse-advantage.html. [Online] [Cited: Nov 20, 2018.]

31. HECK R.K., PEABODY T.D., SIMON M.A., Staging of primary malignancies of bone, CA Cancer J Clin, 56, 2006, p. 366-75.

32. BERGER D. P., ENGELHARDT M., HENß H., MERTELSMANN R., Concise Manual of Hematology and Oncology, 8, 2007, p.748-752.

33. WITTIG J.C., BICKELS J., PRIEBAT D. ET AL. Osteosarcoma: a multidisciplinary approach to diagnosis and treatment, Am Fam Physician, 65, 2002, p. 1123-32.

34. BOGENRIEDER T., HERLYN M. Axis of evil. Molecular mechanisms of cancer metastasis, Oncogene, 22, 2003, p. 6524-36.

35. NGARAJ AN R., CLOHISY D., WEIGEL B., New paradigms for therapy of osteosarcoma, Curr Oncol Rep, 7, 2005, p. 410-4.

36. FRANTI, D. TUFIS, S. GOSCHIN, M. DASCALU, P. L. MILEA, G. STEFAN, T. BALAN, C. SLAV, R. DEMCO, Virtual environment for robots interfaces design and testing, CAS 2005, International Semiconductor Conference; IEEE; volume 1-2, pp. 463-466; 2005; WOS: 000237180300103

37.OPROIU, A. M., LASCAR, I., DONTU, O., FLOREA, C., SCARLET, R., SEBE, I., DOBRESCU, L., MOLDOVAN, C., NICULAE, C., CERGAN, R., BESNEA, D., CISMAS, S., DAVID, D., MURARU, D., NEAGU, T., POGARASTEANU, M.E., STOICA, C., EDU, A., IFRIM, C.F., Topography of the Human Ulnar Nerve for Mounting a Neuro-Prosthesis with Sensory Feedback, Rev. Chim. (Bucharest), 69 , no. 9, p. 2494-2497, 38. WITTE F, KAESE V, HAFERKAMP $\mathrm{H}$, SWITZER E, MEYERLINDENBERG A, WIRTH C], WINDHAGEN H: In vivo corrosion of four 
magnesium alloys and the associated bone response. Biomaterials 2005;26:3557-3563.

39. KRAUST, FISCHERAUER SF, HANZI AC, UGGOWITZER PJ, LOFFLER JF, WEINBERG AM: Magnesium alloys for temporary implants in osteosynthesis: in vivo studies of their degradation and interaction with bone. Acta Biomater 2012;8:1230-1238.

40. MOGA, M.,SEMENESCU, A., CHIVU, R.D., COSTOIU, M.C., MATES, I.M., CALIN, C.I.,AMZA, C. Gh., POGARASTEANU, M. E., OPROIU, A.M., IONITA RADU, F., An Alternative Femoral Stem-Bone Implantation Technique Using an Innovative Short Femoral Stem
Endoprosthesis, Rev. Chim. (Bucharest), 69, no. 11, 2018, p. 32993303.

41. HUEHNERSCHULTE TA, REIFENRATH J, VON RECHENBERG B, DZIUBA D, SEITZ J M, BORMANN D, WINDHAGEN H, MEYERLINDENBERG A: In vivo assessment of the host reactions to the biodegradation of the two novel magnesium alloys ZEK100 and AX30 in an animal model. Biomed Eng Online 2012;11:14.

42. A. M. OPROIU, I. LASCAR, C. MOLDOVAN, O. DONTU, M. PANTAZICA, C. MIHAILA, C. FLOREA, L. DOBRESCU, I. SEBE, R. SCARLET, D. DOBRESCU, T. NEAGU, O. IONESCU, I. C. STOICA and A. EDU, Peripheral Nerve WIFI Interfaces and Electrodes for Mechatronic Prosthetic Hand, ROMJ IST, Volume 21, Number 2, 2018, pp. 129-138

Manuscript received: 20.08 .2018 